\title{
Experience of the cultural route in the space of the tourist landscape
}

\author{
Natalie Moreno-Kamińska \\ (Institute of Contemporary Culture, University of Łódź) \\ ORCID 0000-0003-2543-326X
}

\begin{abstract}
Cultural routes present the values or elements of cultural heritage. They have been permanently inscribed in the landscape of Poland and Europe, thanks to their potential, in the context of historical memory, protection of tangible and intangible heritage, education, and tourism. They are tools for popularizing and bringing out the ethos and identity of the inhabitants. In the context of the development of cultural tourism and the introduction of new trails to the tourist landscape, it is worth considering the role of the experiences acquired by travelers through overcoming the subsequent stages of the cultural route. Participation in activities prepared by trail organizers plays an important role in enabling visitors and natives to learn about the heritage of a given area or to take root in the traditions of a region or nation. The analysis is based on research concerning the tourist landscape, cultural routes, and the author's own experiences
\end{abstract}

Key words:

cultural routes, the tourist landscape, perception, space

\section{Introduction}

One of the themes emerging in the analyses produced by representatives across the social and cultural sciences such as cultural anthropology, cultural science, and sociology, is the question of experiencing cultural diversity and cultural heritage. On the other hand, studies concerning landscape and tourism draw attention to the role of experiencing, feeling, and perception, in shaping the image of the natural, cultural, and tourist landscape. The aim of this article is to present considerations regarding the potential of experiencing cultural routes-registered and officially functioning in cultural tourism, education, and literature-in the context of the cultural (including tourist) landscapes they belong to. History and 
culture recorded in space as well as natural conditions and infrastructure build narrative. It directly affects the tourists' perception of the surroundings and their feelings. The created narrative can in turn become an element influencing the subjective experience that affects how the landscape is perceived. Of particular importance in the context of landscape creation is a contextualization of space that respects the authenticity of the places visited and reflects their identity.

Due to the specificity of the issue, covering the study of cultural routes in terms of the role of experience in in the space of a landscape, the research relies on methods characteristic of various research disciplines. It involved analyzing scientific and popular publications related to cultural heritage, cultural routes, landscapes, and tourism, including to establish a research methodology. Materials that promote cultural routes (mainly the Oscypek Trail) were also researched. Observations were also carried out on selected cultural trails regarding the visitors' experience of the trail.

\section{Cultural and tourist landscape}

The direction in geography, initiated by Alexander von Humboldt, devoted to the landscape as identified with natural values, has evolved over the years. Nowadays, the effects of material and immaterial human activity, and therefore its real content, affecting many factors, including the attractiveness of the area, are equally important in the context of shaping the landscape. The specificity of the landscape, and consequently its typology, is determined by the degree of human interference in the natural environment, the use and the purpose of space, and the occurrence of various kinds of objects.

One such type is the cultural landscape, which was created as a result of the development of civilization and the anthropogenic transformation of the natural landscape. This landscape can be defined as a heterogeneous synthesis, including natural elements and the cultural products of subsequent generations. It is subject to constant changes due to the growing needs and possibilities of man. It is influenced by economic, historical, technological, and social factors, whose impact is variable over time and depends on the potential of the area. They form a specific structure characteristic for a given space. As Urszula Myga-Piątek writes, "the cultural landscape is a peculiar heritage of individual regions, as it documents the activity in the geographical space of societies from many historical epochs" (2012, 13). For this reason, the landscape is often identified with the region's physiognomy. A term that might better reflect perspectives relevant to the development of tourism is "landscape image". These terms are not the same, because the image is created and built on the basis of characteristic, also physiognomic, elements of a given area. Its aim is to attract potential recipients. "In times of globalization, [image] 
leads to shaping the landscape of a specific region as a recognized and sought-after brand" (Myga-Piątek 2012, 25).

The landscape is at the same time a public good, conducive to cultural, economic, and tourist activities, owing to various resources. They constitute kinds of qualities that affect the type of landscape and its dominant functions, whether aesthetic, cultural, cognitive, utilitarian, travel, or recreational. It should be emphasized that the author equates a landscape with a distinctive space, characteristic in its structure, whose distinctive element is its material and immaterial heritage, which is the value of the region. For this reason, not only objects, spatial development, terrain, etc., but also traditions, language and symbolic values should be counted among the significant elements of the landscape (Myga-Piątek 2012, 24-25). The cultural landscape requires taking continuous action to protect and maintain it (Nitkiewicz-Jankowska, and Jankowski 2010, 188), because it "has an impaired ability to self-regulate" (Włodarczyk 2009, 90).

A specific variation of the cultural landscape is the tourist landscape, which should be the result of actions taken in accordance with the principles of sustainable development, aimed at using tourism potential: "all activities leading to the use of its resources and advantages should take into account the preservation of the harmony between natural, cultural, and socio-economic activities" (Skowronek, Jóźwik, and Tucki 2013, 64).

From this perspective, it is important to preserve the balance and authenticity of the landscape when using heritage for tourism purposes. This balance is important because of changes in the symbolic and functional sphere that should preserve the value of the landscape's heritage. They affect the image of space and how it is received by visitors (also in the context of space interpretation). At the same time, an important element of the tourist landscape is the infrastructure, which allows the organization of space, allowing for the service of tourist traffic. These include accommodation facilities, catering facilities, and transport infrastructure (Myga-Piątek 2012, 151). The described development should be skillfully integrated into the landscape, though it often differs physically from the area. Creating a tourist space without maintaining balance can bring negative effects and lead to the development of a landscape subjected to unification and uniformization processes. They often lead to the over-exploitation as well as degradation of the natural and cultural environment. The consequence may sometimes be the standardization of the landscape, and, therefore, the loss of its uniqueness (Myga-Piątek 2012, 25). In this context, commercialization of space is also important. It often has negative effects on elements or places of material cultural heritage, changing a landscape structure. It affects the authenticity of the experienced landscape, characterized by the accumulation of attractions, which are not often strictly related to the specificity of the region.

Among the important feature of the tourist landscape, I want to emphasize several significant issues. The cultural landscape can become a tourist landscape mainly 
due to its potential, attractiveness of the area in terms of the characteristic form of space, including the complementarity of the elements in it that attract the attention of visitors. It is also necessary to have people traveling in a given area, thanks to whom tourist traffic may develop. An immaterial element of the landscape is the image of it, which consists of the expectations, associations, and feelings of visitors (Skowronek, Jóźwik, and Tucki 2013, 72). For this reason, their perception of the landscape is influenced by experiences associated with the encounter of the previously formed image with the real landscape. Therefore, all of the elements, both natural and cultural, shaping the structure and image of space are closely related to the landscape creation process for tourism purposes. The emphasis on certain cultural, historical elements and designation of space, as well as the connotation of places, can allow visitors "to facilitate the unambiguous recognition of the origin of a place, which increases its attractiveness for tourism" (Nitkiewicz-Jankowska and, Jankowski 2010, 189). The accumulation of elements that are interesting for whatever reason for the traveler, which include monuments, thematically related objects, places of historical, cultural, and other significance, affect the valorization of the landscape and its perception. In this context, the cultural route may play a significant role, particularly from the perspective of a person entering a new, culturally distinct area.

\section{Cultural routes in contemporary terminology}

Contemporary researchers more and more often pay attention to the significant role of cultural routes-local, regional, and national-centered on a leading theme in the field of spiritual or material culture, broadly understood. They represent a form of spatial thematization, which facilitates the reception of cultural heritage. Thanks to such trails, travelers perceive them as cultivated and current. The professional literature contains a number of definitions and classifications of cultural routes. Routes connects points in space, creating new narratives around them, influencing the way their landscapes are perceived.

The growing importance of cultural routes in the world can be seen in the formation the International Scientific Committee on Cultural Routes (CIIC) of the International Council on Monuments and Sites (ICOMOS), which is an institution affiliated with UNESCO. In 2008, in Canada, the Committee created the worldwide definition of cultural routes:

Any route of communication, be it land, water, or some other type, which is physically delimited and is also characterized by having its own specific dynamic and historic functionality to serve a specific and well determined purpose, which must fulfill the following conditions: a) It must arise from and reflect interactive movements of people as well as multi-dimensional, continuous, and reciprocal exchanges of goods, ideas, knowledge 
and values between peoples, countries, regions or continents over significant periods of time; b.) It must have thereby promoted a cross-fertilization of the affected cultures in space and time, as reflected both in their tangible and intangible heritage; c) It must have integrated into a dynamic system the historic relations and cultural properties associated with its existence. (CIIC 2008, 3)

The definition is complemented by other aspects that must characterize cultural routes: the context that builds around space, the content of material and immaterial heritage, the intercultural dimension of the whole, the dynamic nature of functioning and geographical location, and determining natural and cultural content (CIIC 2008, 3; Gaweł 2011, 47-48).

A cultural route can be defined as a thematic route, in which the most important aspect is cultural interaction, allowing for gaining new experiences hanks to the feeling of uniqueness and authenticity associated with its cultural heritage. People on the trail have the opportunity to broaden their knowledge, to get acquainted with the history and identity of the area. It should be emphasized that in this article, I am deliberately using the term "cultural route", not the "tourist and cultural route" (szlak turystyczno-kulturowy) proposed by Armin Mikos von Rohrscheidt. He introduces this term in order to "define a group of routes exploiting cultural threads that function outside those officially recognized by the Council of Europe as tourist routes of cultural significance" (Mikos von Rohrscheidt 2009, 385). His idea, however, puts the emphasis on the tourist aspect of routes, and it also points to the occurrence of numerous "attractions of a cultural character" (Mikos von Rohrscheidt 2009, 9). This indicates the selected categorization of heritage elements located on the trail. The aim of this text is to reflect on routes from the perspective of cultural research.

The definition of the cultural route proposed by Łukasz Gaweł $(2011,76)$ refers directly to heritage, stressing that it is not possible to separate the material and immaterial: "through the presentation of material heritage, the route should enable one to learn and promote immaterial heritage, treating both of these areas as an inseparable whole". A given cultural trail affects the local development of the regions in which it is located and their communities. It strengthens the sense of cultural belonging, and identity, through interaction with material and immaterial heritage. The nomenclature allows for different ways of dividing up routes, including tourist and cultural or tourist routes that can also be referred to as cultural routes. They depend on the following:

1. territorial range, including urban, local, regional, supra-regional, national, international, etc.;

2. context, including historical, e.g., biographical, military, archaeological, or technical and industrial, ethnographic, architectural, sightseeing, etc.; 
3. mode of the trip, among others, hiking, car, water, bicycle, horse routes, etc. (Gaweł 2011, 64, 75).

Each type of trail has a different effect on the type of experience acquired and influences how the landscape is perceived. In this article, the research material is based on cultural routes registered and officially operating in cultural tourism.

\section{Route experience and landscape perception}

The concept of experience is included in praxeological science and is related to the category of "action." Yi-Fu Tuan writes that it is a combination of feelings and thoughts (Tuan 1987, 19). People gain experience every day; they acquire knowledge and broaden the horizons of their thinking. As Andrzej Stasiak emphasizes, "until recently, experience was considered a natural, somewhat involuntary, side effect of traveling, not an essential, primary goal" (Stasiak 2016, 195). Contemporary researchers say that the process of cumulating desired experiences plays the most important role in making travel decisions, being the motivation to travel. Experience has a distinctive function. As Agnieszka Niezgoda writes:

The processes of globalization and the related development of communication, with widespread access to the internet, make it easier to search for offers and bookings on your own. As a result, tourists manage their time more independently; they more often decide to organize holidays individually. Tourists want to use their time "effectively". This means that during their trip they want to feel and experience as much as possible. People strive to maximize experiences per unit of time. (Niezgoda 2013, 44-45)

The desire to have new, unique experiences resulting from being in a different environment, climate, and visiting interesting places for their natural or cultural values, mobilizes people to participate in various events - festivals, shows, concerts, feastsinvolving and engaging those who take part. Thanks to this, travelers have the opportunity to see a given culture, to have direct contact with it. Experiences are also usually related to social dimension; they connect with getting to know new people, inhabitants of particular regions, coming from local cultural circles. Travelers want to discover and experience - to a greater or lesser extent- different cultures, including, for example, their way of living, working, customs, traditions, forms of spending free time, preparing meals, etc., in relation to the values and practices cultivated by their own cultural communities. Bilateral comparisons and intercultural communication are the sources of the emergence and development of cultural tourism.

Cultural routes play a special role in the experience of the natural, cultural, and tourist landscape. Taking a trip through cultural routes makes it possible to satisfy various needs, which depend on the place of stay, wealth, habits, desires, etc. The trail somehow changes the way the landscape is understood into systemic. It 
provides new meanings, conceptualizes previously separate places, manifestations of heritage, which are treated as components of a larger whole thanks to the route. As Myga-Piatek wrote of cultural landscapes, we may say that the cultural route documents and connects the activities of societies from many historical eras in geographical space, constituting a path saturated with the heritage of individual regions (Myga-Piątek 2012, 13).

This type of route creates new opportunities for both travelers and tourists. The distinction between these two terms is deliberately used to emphasize the different nature of their motivations and travel destinations. As Krzysztof Podemski $(2005,9)$ writes in Socjologia podróży (Sociology of travel), "the traveler chooses for himself-although usually in accordance with socio-cultural norms, schemes, patterns, or stereotypes - the travel route and the objects, events, or environments with which some form of contact is the goal of leaving 'home." The term is also more adequate due to the active attitude of the traveler, the effort he puts into the expedition; he wants to encounter something new; he is a seeker. On the other hand, the tourist expects experiences prepared for him in some way, and his attitude is more passive. It is associated with the expectation that attractions will fill up his time (Podemski 2005, 21). This approach to travel is superficial: there is no place for reflection on the cultural heritage of the region.

Regardless of the type of route, the traveler or tourist gets to know the points indicated in that space, which, referring to the work of Marc Augé, can be called "places" (Augé 2008). It should be emphasized that space usually refers to an area whose boundaries may be uncertain, and their specific indication will not always be possible. In the "semiotic trend of research, cultural landscapes have many features in common with the social space and its world of meanings" (Plit 2014, 19). The area of a route is influenced by the places that are included in it. They build a narrative on the trail, contextualize it, and create identity. Lucile Grésillon wrote that "places are spaces defined on the map. They have their name and differentiate themselves from others through their materiality and identity" (Grésillon 2010, 21). Places allow one to interpret the space of the trail, which, thanks to it, ceases to be anonymous, obtaining further meanings. Although a cultural route, just like any road, is inseparable from its geographical context, attention should be paid to the process of its "becoming" in the cultural aspect. Every place that fits into its narrative: "is a humanized space. In the process of humanization, the community gives it not only a close relationship with the stories of individual people, but sometimes it also gives them their own lives" (Wolski 2014, 79). For the same reason, a place along a trail can be described as significant, historical, and symbolic. Associations connect with it-differently for each recipient-and connotationsmake it become a distinctive element of a space (Augé 2008, 128, 130).

Cultural routes brings added value. Referring to the landscape, the key aspect is the ability to connect places and objects through a trail in such a way, as to give 
the route the right meaning, create the right context. During one's journey on it, the space connecting successive places takes on a new meaning. As Gaweł writes, the route is "a greater cultural value than the sum of all its components; they gain in importance precisely through mutual interactions" (Gaweł 2011, 48). Therefore, it is treated as a whole-not only as a collection or a series of places, but also the surrounding space. In the same context, but with regard to understanding the landscape, Florian Plit, writes:

in almost all landscape definitions, the emphasis is on the synthetic approach. Numerous examples of this can be found in the cited works of K. Ostaszewska (2002), A. Richling, J. Solon (2011), U. Myga-Piątek (2012), F. Plit (2011) and many other authors. Landscape is a "complex whole," "everything we see," "synthesis of nature and culture," "but a heterogeneous whole." Almost everyone, even those who write about the collection of elements (e.g., D. L. Armand, 1980), pays attention to their mutual connections. Many-if not the majority of-researchers, crossing the boundaries of sensory perception, consider these relations an important part of the landscape. The next step is taken by M. Degórski (2005: 15), who described the landscape as an "objectified visualization of the processes and phenomena occurring in the megasystem of the geographical environment". (Plit 2014, 21)

People moving from place to place in the landscape space experience differences resulting from various forms of transportation (walking, car trail), road conditions, tourism infrastructure, and access to information. They discover other ways of traveling and hear different, often incomprehensible dialects, while searching for the next destinations of their expedition. On many trails, travelers can choose different routes and ways of moving - for instance, on foot, by car, by carriage or sleigh with harnessed horses, or by train. It is possible to go beyond the beaten path. Each visitor will accordingly have different experiences, meet other people, and maybe make acquaintances. Places far away from each other on the trail encourage the visitor to get to know their surroundings. A cultural route inscribed in "a varied landscape with clear links between elements is a more diverse and, at the same time, flexible offer for tourists. This offer ... prompts a deeper, more reflective knowledge" (Kulczyk 2014, 13). The dynamics of "being on the journey" makes it possible to encounter the uniqueness of the landscape in which the trail is set. "The cultural experience offered by the cultural route is associated with the abandonment of a static image of the world" (Kamińska 2013, 320).

There is a clear need to broaden research on the role of the experiences people have while moving through cultural routes, not in the context of the individual places or objects that create the landscape, but above all as a whole, taking into account the process of moving from one place to another. Visitors have the opportunity to develop their knowledge not only because of deliberately made choices or destinations, but also accidentally visited places along the route. 
Cultural routes create greater opportunities for recipients to experience the landscape and to pay attention to its natural and cultural values, which are "values in themselves. It is about such landscape characteristics as exoticism, wildness, culture, typological separateness, uniqueness, diversity, contrast, typicality, picturesqueness, etc." (Andrejczuk 2010, 20). Experiences collected on the cultural route are associated with sensory cognition, often engaging all the senses. The tourist experiences the landscape surrounding him, interpreting received "incentives" in accordance with his own knowledge, experience, needs, and motives (Rogowski 2016, 23). A lot of the incentives on the route make his perception of the landscape more comprehensive and active.

Many tourists visually perceive the uniqueness of the landscape and discover unknown places or monuments while hiking or driving. They stop and visit randomly encountered objects related to the culture of a given region, becoming acquainted with local handicraft, regional costumes, products, flavors and aromas of traditional dishes, etc. All these elements give the recipients the opportunity to experience its genius loci-the difficult to articulate and ephemeral specificity of the place. Traveling along a cultural trail engages a traveler's hearing, because he can listen to the sounds of nature, for example, to the sound of water, singing birds, but also listen to the sounds of music based on scales, performed on regional instruments. The recipient has the opportunity to see and take part in traditional celebrations, festivities, or even to try to learn new things-from crafts, production of traditional or regional products, to folk dance and song. "Landscape incentives are accepted and interpreted in the complex process of perception and become one of the methods of subjective valuation of space, including in terms aesthetics, ethics, emotion, symbolism, and semantics" (Rogowski 2016, 24). The issue of the tourist landscape is connected with the problem of its authenticity and originality, which is particularly important in the context of the potential of cultural routes. As Paweł Zajas writes, "this is where the problem is born, which is associated with the search for the 'real' reality of the regions visited by tourists, while the tourism industry provides them only with performances, staging of reality specially prepared for their use" (Zajas 2008, 216).The commercialization of tourism space often has a negative impact on the elements of material and immaterial cultural heritage that are part of the landscape associated with that space. It weakens its authenticity, striving to accumulate attractions which are not characteristic of the region. It should be noted that "social reality is essentially an ideological creation" (Zajas 2008, 228). In turn, Łukasz Iwasiński emphasizes that "tourists want, above all, to experience authenticity-they look for deep, valuable, and unique sensations in it that allow themselves to be distinguished (Iwasiński 2015, 30). Joseph Heath and Andrew Potter note that the feature of authenticity is not a lack of commodification, but manual execution, natural materials, or traditional destinations of products (Heath and Potter, 2010, 331-332). In many cases, 
the production of regional products, hand-made, from natural ingredients is cultivated on cultural routes. A good example is the Oscypek Trail established in 2011. In huts from April to October, the shepherds make cheese: oscypek, redykołka, and bryndza podhalańska, all entered by the European Commission into the Register of Protected Designations of Origin1.

While the routes proposed by travel agencies often have reality arranged, distorted for maximized profits, cultural routes still seem to be spaces that maintain the principles of sustainable development, even though they are inscribed in the tourist landscape and often have a developed infrastructure. Their role is not to stag the space, but to build narrative around historical and cultural places. It should be emphasized that this narrative cannot be an artificial, adulterated, created form, a kind of "visual cliché" (Zajas 2008, 218), but a reflection of the identity of the space. I am aware of the fact that this is a kind of ideal model that can only apply when all conditions are met. Building a coherent presentation cannot affect the authenticity of the route and landscape; it should be non-invasive and create a coherent, desirable image in the minds of recipients. Its purpose should be the contextualization of heritage, which carries with it an educational value. The tale created on the route, and through it inscribed in a given environment, influences how the landscape is perceived, enriches it, and supports cultural interactions within it. Consequently, it leads to the interpretation of cultural heritage, thanks to its inclusion in a specific context. The narrative contributes to the organization and, interpretation of the space and presents it in accordance in accordance with the central theme of the corresponding cultural heritage. In this way, it imposes the context of the landscape in which the cultural route is inscribed. It makes the space attractive with respect to the given aspect.

In the context of the analyzed issues, it is important to reflect on how the route is presented relative to the landscape. Actions undertaken for this purpose should be skillfully conducted in pursuit of engaging, activating recipients. The presentation's aim is to create an alternative ways of perceiving and experiencing the landscape. It should not lock recipients into a closed discourse. The proposed concept is to use the narrative created through the route as an effective "tool" to support the traveler in reading and understanding the significance of the region's heritage, experiencing the essence of the surrounding landscape, and thus in finding himself in a new space for him. People try to understand themselves through landscape and personal topography (Macfarlane 2018, 36).

Cultural routes should play a significant role in respect of the specificity of their cultural landscapes, preventing standardization, unification processes, and uniformity, so that the tourism infrastructure characterizing the tourist landscape does not adversely affect other aspects important from the perspective of

1 See http://www.szlakoscypkowy.pl/szlak-oscypkowy. 
protecting natural and cultural values. Narration on the trail should, however, be built not only on the basis of cultural heritage, or the history of the region, but also on significant stories about the contemporary people living there, residents, events, and cultivated traditions.

\section{Conclusion}

Cultural routes have influenced the emergence of a new quality in tourism oriented towards getting to know and experiencing cultural landscapes and heritage. The routes enable tourists to consciously search for authentic cultural heritage, aimed at a specific destination-a place on the trail-as well as to accidentally discover heritage, associated with traveling from place to place and being "here and now." Each visitor receives the trail in a unique and different way; therefore, his experience is subjective. There are many factors influencing that subjectivity-demographic, sociological, and ideological-related to the individual's system of values. One's cultural affiliation and personal knowledge about a given area and the culture of the region are also important. During the journey from point to point, the traveler or the tourist has time to reflect on the experiences he has gathered, the impressions of his encounters with a different culture, through interaction with the heritage and inhabitants of the region. A strong commitment to discovering the landscape through the trail will consequently lead to a greater sense of satisfaction with participating in the culture of the region. In this way, an image of the cultural trail and the entire landscape is created in the minds of the recipients. The traveler has the opportunity to learn about local problems and to pay attention to otherwise unnoticed manifestations of heritage and culture. Cultural tourism conducted on the trail influences the subjective aspects of human life and, at the same time, builds the reputation of the area for tourism. As Rogowski wrote $(2016,23)$, it is possible to show that the greater diversity of landscape engages more senses. The consequence is a greater intensity of sensations, which results in increased satisfaction $(2016,23)$. The multi-sensory perception of heritage and the experience of the cultural route in the landscape space guarantee the creation of an interesting and unique destination, characterized by the activities carried out to preserve the authenticity of the landscape in the name of sustainable development principles. The narration created on the trail gives new meaning to the landscape and intensifies the interaction between it and the viewer. Its perfect form has no negative impact on its uniqueness. This narrative is to become a tool for a better understanding of space, which is not a limitation for the cognitive processes of the recipient. It should encourage the recipient to deepen their reflection upon and interpretation of cultural heritage. 


\section{Natalie Moreno-Kamińska}

\section{References:}

Andrejczuk, Wiaczesław. 2010. "Krajobraz a turystyka: aspekt konceptualny" [Landscape and tourism: The conceptual aspect]. Prace Komisji Krajobrazu Kulturowego 14: 15-24.

Augé, Marc. 2008. "Nie-Miejsca: wprowadzenie do antropologii nadnowoczesności: fragmenty." Teksty Drugie: teoria literatury, krytyka, interpretacja 4, no. 112: 127-140. [French original: Non-lieux. Introduction à une anthropologie de la surmodernité. Paris: Le Seuil, 1992.]

CIIC. 2008. "The ICOMOS charter on Cultural Routes". 16th General Assembly of ICOMOS. Published October 4, 2008

Gaweł, Łukasz. 2011. Szlaki dziedzictwa kulturowego. Teoria i praktyka zarządzania [Cultural heritage routes:

Theory and practice of management]. Kraków: Wydawnictwo Uniwersytetu Jagiellońskiego.

Grésillon, Lucile. 2010. Sentir Paris. Bien-être et materialité des lieux. Paris: Edition Quae.

Heath, Joseph and Andrew Potter. 2010. Bunt na sprzedaż. Dlaczego kultury nie da się zagłuszyć. Warszawa:

Muza. [English original: The Rebe/ Sell: Why the Culture Can't be Jammed. Chichester: Capstone, 2004.] Iwasiński, Łukasz. 2015. "Turystyka jako rynek doświadczeń" [Tourism as an experience market]. Kultura Popularna 2, no. 44: 28-38.

Jałowiecki, Bohdan. 2011. "Miejsce, przestrzeń, obszar" [Place, space, area]. Przegląd Socjologiczny 60: 9-28.

Kamińska, Krystyna. 2013. "Szlak kulturowy — nowa strategia uobecniania przeszłości" [Cultural route — the new strategy of representing the past]. Zeszyty Naukowe Ostrotęckiego Towarzystwa Naukowego 27: $319-329$

Kulczyk, Sylwia. 2014. "Atrakcyjność turystyczna krajobrazu — przykłady podejścia Systemowego" [The touristic attraction of the landscape — examples of systematic approaches]. Turystyka Kulturowa 4: 6-15 Macfarlane, Robert. 2018. Szlaki. Opowieści o wędrówkach. Translated by Jacek Konieczny. Poznań: Wydawnictwo Poznańskie. [English original: The Old Ways: A Journey on Foot. London: Penguin Books, 2012] Myga-Piątek, Urszula. 2012. Krajobrazy kulturowe. Aspekty ewolucyjne i typologiczne [Cultural landscapes: Evolutionary and typological aspects]. Katowice: Uniwersytet Śląski.

Mikos von Rohrscheidt, Armin. 2009. "Polskie szlaki turystyczno-kulturowe: kryteria i zasady waloryzacji potencjału" [Polish tourist and cultural routes: Criteria and principles for valorizing their potential] Turystyka kulturowa 4: 4-28.

Niezgoda, Agnieszka. 2013. "Turystyka doświadczeń — dawna czy nowa forma turystyki?" [Experience tourism — an old or new form of tourism?]. In Nowe-stare formy turystyki w przestrzeni, edited by Robert Wiluś and Jolanta Wojciechowska, 37-47. Łódź: Wydawnictwo Uniwersytetu Łódzkiego.

Nitkiewicz-Jankowska, Anna, and Grzegorz Jankowski. 2010. "Krajobraz kulturowy jako walor turystyczny" [Cultural landscape as a tourist value]. Prace Komisji Krajobrazu Kulturowego 14: 185-193.

Plit, Florian. 2014. "Krajobraz w przestrzeni czy przestrzeń w krajobrazie" [Landscape in the space or the space in the landscape]. Prace Komisji Krajobrazu Kulturowego 24: 19-26.

Podemski, Krzysztof. 2005. Socjologia podróży [Sociology of travel]. Poznań: Wydawnictwo Naukowe Uniwersytetu im. A. Mickiewicza.

Rogowski, Mateusz. 2016. "Multisensoryczność krajobrazu jako inspiracja w kreowaniu produktu turystycznego" [The multi-sensory landscape as an inspiration in the creation of a tourism product] Turyzm 26, no. 2: 23-32. 
Oscypek Trail [directory], Zakopane: Stowarzyszenie Szlak Oscypkowy [publication date not specified]. Skowronek, Ewa, Marta J. Jóźwik, and Andrzej Tucki. 2013. "Krajobraz turystyczny — koncepcja teoretyczna" [Tourist landscape —-theoretical concept]. In Nowe-stare formy turystyki w przestrzeni, edited by Robert Wiluś and Jolanta Wojciechowska, 63-77. Łódź: Wydawnictwo Uniwersytetu Łódzkiego.

Stasiak, Andrzej. 2016. "Doświadczenie — stary-nowy paradygmat turystyki" [Experience — an old-new paradigm of tourism]. Folia Turistica 41: 191-216.

Tuan, Yi-Fu. 1987. Przestrzeń i miejsce. Perspektywa doświadczania. Translated by Agnieszka Morawińska. Warszawa: Państwowy Instytut Wydawniczy. [English original: Space and Place: The Perspective of Experience. Minneapolis: University of Minnesota Press, 1977.]

Włodarczyk, Bogdan. 2009. "Krajobrazy przestrzeni turystycznej" [Landscapes of tourist space]. Turyzm 19, no.1-2: 89-97.

Wolski, Aleksander. 2014. "Percepcja przestrzeni w społeczności lokalnej" [Perception of space in the local community]. Prace Komisji Krajobrazu Kulturowego 24: 77-86.

Zajas, Paweł. 2008. "O 'autentyczności' i ponowoczesnym rozumieniu doświadczenia turystycznego" [About "authenticity" and the post-modern understanding of tourist experience]. Teksty Drugie. Teoria literatury, krytyka, interpretacja 4: 215-230. 